\title{
Hepatobiliary Infestation by Ascaris lumbricoides
}

\section{BQ Sander ${ }^{1 *}$, EP Silva ${ }^{2}$, SR Farfan ${ }^{3}$, LD Conceição ${ }^{4}$, SG Godinho ${ }^{5}$, WCC Vieira $^{6}$, FMB Pires ${ }^{7}$, HG Sampaio ${ }^{8}$, JR Pereira ${ }^{9}$, FRB Miranda ${ }^{10}$, CHR Castro $^{\mathbf{1 1}}$ and IS Barra}

${ }^{1}$ Sander Medical Center, Brazil

${ }^{2}$ Hospital Portela, Brazil

${ }^{3}$ Hospital of Santa Rosália, Brazil

${ }^{4} \mathrm{HC}$ of Alagoinhas, Brazil

${ }^{5}$ Hospital Imaculada Conceição, Brazil

${ }^{6}$ Clínica AMA, Brazil

${ }^{7}$ Tower Center, Brazil

${ }^{8}$ HapClínica Pituba, Brazil

${ }^{9}$ GV Clínicas, Brazil

${ }^{10}$ Clínica São José,, Brazil

${ }^{11}$ Clínica São Francisco de Assis, Brazil

${ }^{12}$ Hospital Portela, Brazil

*Corresponding Author: BQ Sander, Sander Medical Center, Brazil.
Received: March 12, 2020

Published: March 30, 2020

(C) All rights are reserved by BQ Sander., et al.

\section{Abstract}

Hepatobiliary infestation by Ascaris lumbricoides is a common condition with extremely rare complications such as liver abscess, until most common complications such as obstructive jaundice. Prevalence is more frequent in developing countries with poor sanitary conditions, where the prevalence of Ascaris is high.

Keywords: Ascaris lumbricoides; Hepatobiliary Infestation

\section{Aim of the Study}

The aim of this study was review the literature covering issues such as diagnosis and treatment of hepatobiliary infestation and its complications.

\section{Materials and Methods}

We seek papers in Pubmed ${ }^{\circledR}$ using the keywords ascariasis, pyogenic hepatic abscess, biliary ascariasis, ERCP, endoscopy, ultrsonography, hepatobiliary ascariasis.

\section{Discussion}

Ascariasis is a disease caused by the roundworm Ascaris lumbricoides, being the most common intestinal parasite in the world, reaching about $25 \%$ of the population $[2,3,10-25,27,28]$ and accounts for about 20,000 deaths per year $[2,3,10]$ affecting both sexes equally $[2,3,10,13,20-25,27,28]$.

The migratory tendency of Ascaris lumbricoides favors entry into the biliary tract and pancreas, causing obstructive jaundice with ascending cholangitis, or pancreatitis. Younger forms amounting to intrahepatic bile ducts can cause liver abscesses [2,3,12,13,24-27].

After entering the bile duct Ascaris excretes various types of polypeptides that produce allergic reactions causing spasm of the sphincter of Oddi by the action of chemical irritants [25]. Cholestasis resulting translocation of intestinal bacteria associated with the worm into the bile duct leading to pyogenic ascending cholangitis, cholecystitis, pancreatitis and pancreatic abscess.

Liver abscesses pyogenic side infestation Ascaris are rare comprising about $1 \%$ of all cases, which may be greater prevalence in endemic areas [9].

Pregnant females may migrate to the bile ducts through which minors may alcansar where the liver parenchyma after the deposition of eggs they die. Through this migration can be bacterial translocation by the worm, which would lead to pyogenic abscesses with polymicrobial flora in general source intestinal [25].

\section{Conclusion}

Ascaris infection in most cases are asymptomatic and without major repercussions, but the complications, though rare, are of great morbidity, and outcome and severity than when the worm is alive and when the worm is dead, being more severe than those in the worm is dead, needing early intervention in cases of obstruction, or bowel, or biliary tract. 
Conservative treatment in cases of hepatobiliary infestation is still the mainstay of management of complications, with the exceptions in cases where a flaw in the conservative treatment, pyogenic cholangitis or acute cholecystitis unresolved, worms associated calculations, liver abscess.

\section{Bibliography}

1. Mattos Angelo Alves De and Dantas-Corrêa Esther Buzaglo. “Tratado de Hepatologia". $1^{\text {st }}$ edition. Rio de Janeiro: Rubio (2010).

2. Prado Joaquim. "Tratado das Enfermidades Gastrintestinais e Pancreáticas”. $1^{\text {st }}$ edition. São Paulo: Roca (2008).

3. Dani Renato. "Gastroenterologia Essencial". $3^{\text {rd }}$ edition. Rio de Janeiro: Guanabara Koogan (2006).

4. Floch Martin H., et al. "Gastroenterologia de Netter". $1^{\text {st }}$ edition. Philadelphia: Elsevier Saunders (2005).

5. Gardner Ernest., et al. "Anatomia". $4^{\text {th }}$ edition. Rio de Janeiro: Guanabara Koogan, (1998).

6. Gray Henry. "Tratado de Anatomia Humana”. 24 $4^{\text {th }}$ edition. Rio de Janeiro: Guanabara Koogan (1946).

7. Rohen Johannes W and Yokochi Chihiro. "Anatomia Humana”. $2^{\text {nd }}$ edition. São Paulo: Manole (1989).

8. Sobotta Johannes. "Atlas de Anatomia Humana". $20^{\text {nd }}$ edition. Rio de Janeiro: Guanabara Koogan (1995).

9. Solto José Dutra and Fontes, Cor Jésus Fernandes. “O Fígado e as Infecções". In: MATTOS, Angelo Alves de Dantas-Corrêa, Esther Buzaglo. Tratado de Hepatologia. $1^{\text {st }}$ edition. Rio de Janeiro: Rubio (2010): 22 277-280.

10. Cunha Aloísio Sales da and Ferrari Maria de Lourdes de Abreu. "Parasitoses Intestinais". In: PRADO, Joaquim. Tratado das Enfermidades Gastrintestinais e Pancreáticas. $1^{\text {st }}$ edition. São Paulo: Roca 66 (2008): 927-928.

11. Chebli Júlio Maria Fonseca Gaburri., et al. "Pancreatite Aguda". In: Prado, Joaquim. Tratado das Enfermidades Gastrintestinais e Pancreáticas. $1^{\text {st }}$ edition. São Paulo: Roca 80 (2008): 1110-1114.

12. Alam S. "Comparative study on presentation of biliary ascariasis with dead and living worms". Saudi Journal of Gastroenterology 16.3 (2010): 203-206.

13. Ogata H., et al. "Multilocular pyogenic hepatic abscess complicating Ascaris lumbricoides infestation". Internal Medicine 39.3 (2000): 228-230.

14. Seddik H., et al. "Liver abscess revealing an hepatobiliary ascariasis". Gastroenterologie Clinique et Biologique 32.11 (2008): 979-981.

15. Astudillo JA., et al. "Ascariasis in the hepatobiliary system: laparoscopic management". The Journal of the American College of Surgeons 207.4 (2008): 527-532.
16. Târcoveanu E., et al. "Unusual forms of liver abscesses". Revista Medico-Chirurgicala a Societatii de Medici si Naturalisti din Iasi 112.3 (2008): 688-697.

17. Robbani I., et al. "Worms in liver abscess: extensive hepatobiliary ascariasis”. Digestive and Liver Disease 40.12 (2008): 962.

18. Das CJ., et al. "Imaging of ascariasis". Australasian Radiology 51.6 (2007): 500-506.

19. Alam S., et al. "Presentation and endoscopic management of biliary ascariasis". Southeast Asian Journal of Tropical Medicine and Public Health 38.4 (2007): 631-635.

20. Bari S. "Ascaris liver abscess in children". Journal of Gastroenterology 42.3 (2007): 236-240.

21. Malik AH., et al. "Management of hepatobiliary and pancreatic ascariasis in children of an endemic area". Pediatric Surgery International 22.2 (2006): 164-168.

22. Bahú Mda G., "Hepatobiliary and pancreatic complications of ascariasis in children: a study of seven cases". Journal of Pediatric Gastroenterology and Nutrition 33.3 (2001): 271-275.

23. Khuroo MS. "Hepatobiliary and pancreatic ascariasis". Indian Journal of Gastroenterology 20.1 (2001): C28-C32.

24. Chakrabarti I., et al. "Radio-pathological diagnosis of hepatobiliary ascariasis: A rare entity". Journal of Cytology 28.3 (2011): 114-116.

25. Ferreira MA., et al. "Pyogenic liver abscess in children: some observations in the Espírito Santo State, Brazil". Archives of Gastroenterology 34.1 (1997): 49-54.

26. Nagakura K., et al. "Serologic findings in hepatic ascariasis: a case report". Tohoku Journal of Experimental Medicine 167.2 (1992): 121-126.

27. Mukhopadhyay M. "Biliary ascariasis in the Indian subcontinent: a study of 42 cases". Saudi Journal of Gastroenterology 15.2 (2009): 121-124.

28. Lee KH., et al. "Recurrent pancreatitis secondary to pancreatic ascariasis". Medical Journal 50.6 (2009): e218-e219.

\section{Assets from publication with us}

- Prompt Acknowledgement after receiving the article

- Thorough Double blinded peer review

- Rapid Publication

- Issue of Publication Certificate

- High visibility of your Published work

Website: www.actascientific.com

Submit Article: www.actascientific.com/submission.php

Email us: editor@actascientific.com

Contact us: +919182824667 